\title{
Revision of the family Dipterocarpaceae in Angola
}

\author{
L. Catarino ${ }^{1,2}$, E.S. Martins ${ }^{1}$, J.A. Abreu ${ }^{1}$, R. Figueira ${ }^{1,2}$
}

Key words

Dipterocarpaceae

endemism

Marquesia

Monotes

new species

Southern Africa

taxonomy

\begin{abstract}
The diversity of Dipterocarpaceae in Angola is updated to 24 taxa, two species of Marquesia and 22 species and subspecies of Monotes. A new species is described and four new records (three species and one subspecies) are added to the Flora of Angola. The new species, Monotes paivae, occurs in the province of Bié, central Angola. Its diagnostic characters are a persistent indumentum on the entire upper surface of leaves and a woollytomentose indumentum in the lower surface of adult leaves. A key to the species and the respective descriptions is presented. The species of Monotes endemic in the country are mapped and their conservation status is discussed.

Resumo A diversidade da família Dipterocarpaceae em Angola é actualizada para 24 taxa, duas espécies de Marquesia e 22 espécies e subespécies de Monotes. Uma nova espécie é descrita e quatro novos registos (três espécies e uma subespécie) são adicionados à flora de Angola. A nova espécie Monotes paivae, ocorre na províncias do Bié, no centro do país. É caracterizada por possuir indumento persistente em toda a página superior das folhas e um indumento lanoso-tomentoso na página inferior das folhas adultas. Apresenta-se uma chave das espécies e a respectiva descrição. As espécies de Monotes endémicas em Angola são cartografadas e o seu estatuto de conservação discutido.
\end{abstract}

Published on 25 February 2013

\section{INTRODUCTION}

Dipterocarpaceae is a family of tropical trees and shrubs. In a wide sense, it includes three subfamilies: Dipterocarpoideae in Asia, Pakaraimoideae in South America and Monotoideae in Africa, Madagascar and South America (Maguire \& Ashton 1977, Londoño et al. 1995). However, the status of Pakaraimoideae and Monotoideae as subfamilies of the Dipterocarpaceae is a matter of discussion, and Kostermans (1985) argues that species belonging to these two subfamilies are closely allied to the Tiliaceae. In fact, the same author has already created the family Monotaceae (Kostermans 1989) but further studies, based on the analysis of cloroplastidial nucleotide sequences (Dayanandan et al. 1999) indicated that Dipterocarpaceae, including Monotes, form a monophyletic group, supporting the preservation of the family in its broad sense. Dipterocarpaceae s.l. contains 20 genera and about 580 species (Maury-Lechon \& Curtet 1998), most of them included in the Dipterocarpoideae subfamily, an important component of the Asiatic lowland rainforests.

The three subfamilies in Dipterocarpaceae are separated by Maguire \& Ashton (1977) by a set of vegetative and reproductive characters, namely wood anatomy and flower, fruit and pollen features.

The African and Madagascan Dipterocarpaceae belong to the genera Monotes and Marquesia. Pseudomonotes, a new genus described for South America by Londoño et al. (1995) was also included by these authors in this subfamily. Monotes comprises about 30 species of shrubs to medium-sized trees, without buttresses, distributed in continental Africa and Madagascar. The leaves are mostly rounded to retuse at the apex, rarely acumi-

Jardim Botânico Tropical, Instituto de Investigação Científica Tropical; Trav. Conde da Ribeira 9, 1300-142 Lisboa, Portugal;

corresponding author e-mail: Imfcatarino@gmail.com.

2 CIBIO, Centro de Investigação em Biodiversidade e Recursos Genéticos,

Campus Agrário de Vairão, Universidade do Porto, 4485-601 Vairão, Portugal. nate, with more or less rounded extra-floral nectaria at the base of the midrib above and sometimes additional ones in lower nerve axils. The main distribution area of the genus in Africa comprises woodlands and savanna woodlands dominated by Leguminosae (Brachystegia - Isoberlinia woodlands) in central and southern Africa, namely in the Democratic Republic of the Congo, Angola, Zambia and Mozambique, extending from the Atlantic to the Indian coasts at the south of Congolian forest, in an ecologically semi-dry belt (Aubréville 1976). A single species, $M$. kerstingii Gilg has a distribution area separate from the main area of the genus in continental Africa. It occurs from Mali to Sudan, in a belt of semi-dry Sudanian climate at the north of the Congolian forest area. Another species, M. madagascariensis Humbert, is endemic to southern Madagascar (Aubréville 1976). Marquesia comprises three species of evergreen, mediumsized to tall trees, buttressed, with persistent, acuminate leaves, midrib and lateral nerves prominent beneath and tertiary venation densely reticulate. It is endemic to the forests and woodlands of central Tropical Africa (Verdcourt 1989), often forming pure or almost pure populations, and occurs in Angola, the Democratic Republic of the Congo, Equatorial Guinea, Gabon, Tanzania and Zambia, reaching the western Atlantic coast, but not the Indian coast (Aubréville 1976, Sosef 2010b).

\section{The taxonomy of Dipterocarpaceae in Africa}

The first record of Dipterocarpaceae in Africa was published by Oliver (1868) in the first volume of the Flora of Tropical Africa (FTA). This author based many of his descriptions on the specimens collected by Friedrich Welwitsch during his Angolan campaigns subsidized by the Portuguese Government. Among the large number of specimens collected by Welwitsch, Oliver described Vatica africana Welw. ex Oliv., a shrub or small tree occurring near Huila, in the south of Angola. This species was originally described by Welwitsch (1869), but his work was published after Oliver's FTA, in which the name was effectively and validly published. In FTA, Oliver recognized four varieties of $V$. africana: glabra, glomerata, hypoleuca and laxa. The

(c) 2013 Nationaal Herbarium Nederland

You are free to share - to copy, distribute and transmit the work, under the following conditions:

$\begin{array}{ll}\text { Attribution: } & \text { You must attribute the work in the manner specified by the author or licensor (but not in any way that suggests that they endorse you or your use of the work). } \\ \text { Non-commercial: } & \text { You may not use this work for commercial purposes. }\end{array}$

Non-commercia:

For any reuse or distribution, you must make clear to others the license terms of this work, which can be found at http://creativecommons.org/licenses/by-nc-nd/3.0/legalcode. Any of the above conditions can be waived if you get permission from the copyright holder. Nothing in this license impairs or restricts the author's moral rights. 
genus Vatica is presently included in Dipterocarpoideae, the Asian subfamily, but the variety hypoleuca is now considered a true species (Monotes hypoleucus (Welw. ex Oliv.) Gilg). In the same year of the publication of that volume of FTA, De Candolle (1868) published an account of the Dipterocarpaceae, in which $V$. africana is separated from Vatica. Based on the differences in floral morphology between $V$. africana and the other species of the genus, the author created the new genus Monotes A.DC. and included $V$. africana in it as Monotes africanus (Welw. ex Oliv.) A.DC. Monotes was subsequently accepted by Hiern (1896) in the 'Catalogue of Plants Collected in Angola by Welwitsch' and by later authors. After some discussion on the inclusion of Monotes in the Dipterocarpaceae, Gilg (1899) suggested that Monotes represents a subfamily, the Monotoideae, which diverged from the main stock, the Dipterocarpoideae, at an early age (Bancroft 1935). In the cited work, Gilg recognized seven species of Monotes. The more recent accounts of the genus in Africa refer to 32 to 37 species (Verdcourt 1989, African Plants Database (http://www.ville-ge.ch/musinfo/bd/cjb/africa/, last accessed 6 July 2011)), but these figures are considered an overestimation by some authors including Verdcourt (1989).

Marquesia, the other genus of Dipterocarpaceae in Africa, was created by Gilg (1908a) to accommodate a new species described on basis of a collection by Marques in Angola. Gilg named this species Marquesia macroura and originally included the genus in the Flacourtiaceae. However, the validity of the name Marquesia is presently a matter of discussion. Based on a set of drawings made at the Paris herbarium and distributed to some other European herbaria, Sosef (2010a, b) argues that Trillesanthus is a validly published name and must replace Marquesia. On the other hand, Van Rijckevorsel (2011) raises some doubts about the validity of the publication of Trillesanthus and defends that Marquesia is a well-established name that deserves nomenclatural protection. As the matter is not completely clarified, in this work we adopt a conservative perspective, maintaining the use of Marquesia.

\section{The diagnostic characters in Monotes and Marquesia}

The two genera of African Dipterocarpaceae have distinct ecological and taxonomical features. The species of Marquesia occur in deciduous forests and woodlands, while the species of Monotes grow in dry to semiarid environments, mainly in savanna and savanna woodland. As in the Asian forest Dipterocarps, the African forest species (genus Marquesia) possess a well-defined set of characters. On the other hand, Monotes shows a large variability in vegetative characters, in particular in the type and density of the indumentum of leaves, which makes species delimitation difficult. As noted by Ashton (1982), some Malesian species growing in dry environments show also a remarkable variability in the amount and density of indumentum. Nevertheless, in the Malesian flora those variations are considered of infraspecific level, while in Africa they are used to delimit species. In this revision we adopt a conservative perspective and, when we do not have new data to support a change in the established taxonomy, we accept it. It is true that, with the set of characters used, the separation of the taxa in Monotes is often difficult. It is possible that, after further study on the taxonomy of Dipterocarpaceae in Africa, using new and intensive collections and modern techniques, including molecular biology, the taxonomy in this genus will change.

The main characters used for species differentiation in the Monotoideae subfamily, particularly in Monotes, are vegetative. Most flower and fruit characters show large variation within each species and are not commonly used for species distinction. The main characters with diagnostic importance in the genus are largely retrieved from mature (but not old) leaves on normally grown shoots (Bancroft 1939a).
The size, density and distribution of the indumentum over leaf surface, as well as the type of hairs are characters used to characterise most Monotes species. The size and general shape of leaf blades, the shape of apex and base, the venation density and type, the length of petioles, and the prominence of secondary and tertiary veins are also important to characterise the species. The position, type and size of the inflorescences are also considered to distinguish some species. Nevertheless, considering the intra-specific variation in morphological characters and changes during maturation processes, particularly in leaves, it is often difficult to select an appropriate set of features to characterise each species and a key comprising the whole genus is still not published.

Some authors consider the species of Monotes arranged in groups or types, depending on the main distinctive characters, which are chiefly leaf features. According to the presence, type, distribution and density of indumentum on both leaf surfaces, and to the shape and size of leaves, Bancroft (1939a), in her taxonomic survey on the genus Monotes in Africa, considers eight main types or lines of development: Katangensis, Glaber, Africanus, Glandulosus, Caloneurus, Hypoleucus, Discolor and Homblei. On the other hand, Duvigneaud (1949) considers five groups of Monotes species in the southern Congo and neighbouring regions: Africanus, Caloneurus-angolensis, Hypoleucus, Magnificus and Dasyanthus-katangensis.

\section{The Angolan Dipterocarpaceae}

In Africa, Angola is one of the countries with the largest number of Dipterocarpaceae species, in particular Monotes. The available data for the country record two species of Marquesia and 19 species of Monotes, from which 10 are considered endemics for the country (Bancroft 1937, Figueiredo \& Smith 2008). Angola seems to be a centre of endemism of this genus, bearing more than half of the African species described. In the last decades the botanical study of the Angolan flora has been hindered due to political instability. Nevertheless, since the publication of the last studies on the Angolan Dipterocarpaceae (Bancroft 1937, Exell \& Mendonça 1951), a large amount of specimens has been collected throughout the country, in particular during the decades of 1950-1970. The taxonomy of the Angolan Monotes is not yet well established. According to Verdcourt (1989), it needs a reassessment and the number of species presently accepted might be reduced.

In this work we present a revision of the Angolan Dipterocarpaceae based on the specimens housed at COI, LISC and LISU herbaria, and on the type specimen images available at JSTOR Plant Science.

\section{MATERIAL AND METHODS}

Herbarium collections of Angolan Dipterocarpaceae were consulted at COI (Botanical Institute, University of Coimbra), LISC (Tropical Research Institute (IICT), Lisbon) and LISU (Botanical Garden, University of Lisbon) (abbreviations after Holmgren et al. 1990). Additionally, type specimen images available at JSTOR Plant Science website (http://plants.jstor.org/, last accessed 6 July 2011) were examined.

All dimensions given are for dried material. For each species, the collections from each Angolan province are cited. Code for the provinces: $\mathrm{BE}$ - Benguela; $\mathrm{BI}$ - Bié; $\mathrm{BO}$ - Bengo; $\mathrm{CA}$ - Cabinda; CC - Cuando-Cubango; CN - Cuanza Norte; CS - Cuanza Sul; CU - Cunene; HA - Huambo; HI - Huíla; LA Luanda; LN - Lunda Norte; LS - Lunda Sul; MA - Malange; MO - Moxico; NA - Namibe; UI - Uíge; ZA - Zaire.

Endemicity has been checked against the published floras, checklists and monographs of the neighbouring territories, namely Namibia (Craven 1999) and Zambia (Phiri 2005), including 
Flora Zambesiaca (Duvigneaud 1961) and the monograph of Monotes by Duvigneaud (1949).

Specimen metadata were used to ascertain the conservation status of the endemic species following the IUCN Red List parameters (IUCN 2010), using a country-wide geographical extent. The information included in the herbarium vouchers was used to assess the criterion B - Geographic range of species, in the form of either B1 (extent of occurrence) and/or B2 (area of occupancy) and the criterion D - Very small or restricted population (Willis et al. 2003).

All specimens were initially georeferenced using location data available on the labels and a series of georeferenced maps at the $1: 100000$ scale (Ministério do Ultramar 1963-1967). Additionally, online gazetteers BioGeomancer (http://www. biogeomancer.org/) and GEOLocate (http://www.museum. tulane.edu/geolocate/) were used. The area of occurrence for each species was calculated considering a 2 by $2 \mathrm{~km}$ grid drawn over the occurrence area (IUCN 2010), using the ArcGIS v. 10.0 software (ESRI 2010).

\section{KEY TO THE ANGOLAN DIPTEROCARPACEAE}

As already noted by several authors (Bancroft 1939a, Duvigneaud 1944), the taxonomy of the African Dipterocarps, and in particular of the genus Monotes is based mainly on leaf characteristics, since the qualitative characters of flowers and fruits show a remarkable uniformity. Given that, the key presented here is based mainly on vegetative characters.

1. Tall trees with straight trunks, buttressed, branchlets densely longitudinally channelled, leaves acuminate, androgynophore present .................. Marquesia

1. Shrubs or small trees with irregular trunks, without buttresses, branchlets more or less smooth, leaves rarely acuminate, androgynophore absent . . . . . . . . 2. Monotes

\section{Marquesia}

1. Lower surface of leaves glabrous except for the midrib and lateral nerves, with sparse hairs, petiole up to $1 \mathrm{~cm}$ long .

1. M. acuminata

1. Lower surface of leaves covered with a short and dense indumentum, petiole over $1 \mathrm{~cm}$ long .... 2. M. macroura

\section{Monotes}

1. Upper leaf surface of adult leaves glabrous or with hairs only on the midrib and lateral nerves $\ldots \ldots \ldots \ldots \ldots \ldots 2$

1. Upper leaf surface of adult leaves with indumentum of simple and/or stellate hairs . . . . . . . . . . . . . . . 10

2. Lower surface of adult leaves glabrous . . . . . . . . 3

2. Lower surface of adult leaves pubescent $\ldots \ldots \ldots \ldots 4$

3. Lateral nerves in 9-11 pairs .......... 14. M. glaber

3. Lateral nerves in 13-18 pairs ..... 24. M. xasenguensis

4. Interreticular areoles of lower leaf surface glabrous ... 5

4. Interreticular areoles of lower leaf surface pubescent or hidden by the indumentum of the veins . . . . . . 6

5 . Lower leaf surface with curled hairs on the nerves ...... ... . . . . . . . . . . . . . . . . . 5. M. africanus

5. Lower leaf surface with sparse simple hairs and numerous glandular hairs on the nerves ... . . . 23. M. rubriglans

6. Blade of adult leaves up to $8 \mathrm{~cm}$ long . . . . . . . . . 7

6. Blade of adult leaves $8-20(-25) \mathrm{cm}$ long . . . . . . . . 8

7. Lower leaf surface with disperse straight hairs on the nerves, interreticular areoles with a short dense whitish indumentum of curled hairs ................. 18. M. loandensis

7. Lower surface tomentose with simple, short hairs on veins and interreticular areoles ......... . 20. M. noldeae
8. Lower leaf surface whitish, with sparse straight hairs and yellow glands on the nerves and dense, short curled hairs covering the veins and areoles .........11. M. discolor

8. Lower leaf surface yellowish, brownish or greyish, minute stellate hairs covering the interreticular areoles . . . . 9 9

9. Adult leaves $10-18 \mathrm{~cm}$ long, lower surface yellowish to brownish, with curled hairs on the nerves and veins....

7. M. caloneurus

9. Adult leaves $8-11 \mathrm{~cm}$ long, lower surface greyish to brownish, with short cottony hairs on the nerves and veins ...

12. M. elegans

10. Adult leaves more than $10 \mathrm{~cm}$ long . . . . . . . . . . 11

10. Adult leaves up to $10 \mathrm{~cm}$ long . . . . . . . . . 17

11. Upper surface of leaves with simple, straight hairs only .

11. $\ldots \ldots \ldots \ldots \ldots \ldots \ldots \ldots \ldots \ldots \ldots \ldots \ldots \ldots \ldots \ldots \ldots \ldots \ldots$

11. Upper surface of leaves with both simple and stellate hairs. . . . . . . . . . . . . . . . . 16

12. Apex of leaves rounded, truncate or emarginated, areoles glabrous or with stellate hairs . . . . . . . . . 13

12. Apex of leaves typically acuminate (or in the same plant leaves acuminate and acute, obtuse, rounded or emarginate), areoles with stellate hairs and yellow to amber

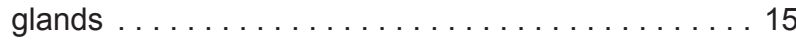

13. Areoles on lower leaf surface covered with stellate hairs ............ . 4. M. adenophyllus subsp. homblei

13. Areoles on lower leaf surface glabrous or subglabrous 14

14. Lower leaf surface subglabrous, with only sparse simple and penicillate hairs on the nerves and veins, venation not prominent ....... 3. M. adenophyllus subsp. delevoyi

14. Lower leaf surface pubescent, with the midrib and lateral nerves covered with penicillate and simple flexuous hairs, venation prominent ........ 16. M. hutchinsonianus

15. Leaf blades $7-13$ by $4-7(-10) \mathrm{cm}$, lower surface tomentose, with dense flexuous hairs on the nerves and veins masking the areoles; lateral nerves in 10-15 pairs. . . . .

9. M. dasyanthus

15. Leaf blades $8-15$ by $5-12 \mathrm{~cm}$, lower surface with curled hairs on the nerves and veins not masking the areoles; lateral nerves in 14-18 pairs . . . . . . 19. M. mutetetwa

16. Lower leaf surface with a dense indumentum of short curled hairs on the nerves and veins, less dense in the areoles . . . . . . . . . . . . . . . . . . . . 10. . dawei

16. Lower leaf surface with a continuous woolly-tomentose indumentum of long flexuous hairs, hiding the interreticular areoles. . . . . . . . . . . . . . 21. M. paivae

17. Largest adult leaves $7-10 \mathrm{~cm}$ long . . . . . . . . 18

17. Largest adult leaves up to $6 \mathrm{~cm}$ long . . . . . . 21

18. Leaves discolorous, lower surface yellowish, light brown or cream-whitish . . . . . . . . . . . . . . 19

18. Leaves concolorous, lower surface brown . . . . . 20

19. Upper leaf surface with short penicillate hairs, more abundant on the midrib and lateral nerves, petiole $1.1-2.2 \mathrm{~cm}$ long, canaliculate............ 6. M. angolensis

19. Upper leaf surface with short simple and stellate hairs and resiniferous glands, petiole $1.6-2.1 \mathrm{~cm}$ long, terete . . . .

22. M. pearsonii

20. Upper leaf surface covered with stellate hairs, petiole 1.5-2 $\mathrm{cm}$ long, terete. . . . . . . . . . 17. M. hypoleucus

20. Upper leaf surface with simple and glandular hairs; petiole $2-3 \mathrm{~cm}$ long, canaliculate ....... 8. . . carrissoanus

21. Nerves and veins in lower leaf surface covered with a dense indumentum of curled hairs, masking the areoles......

15. M. gossweileri

21. Nerves and veins in lower leaf surface covered with short curled hairs, not masking the areoles .... 13. M. engleri 


\section{TAXONOMIC TREATMENT}

\section{Marquesia Gilg}

\section{Trillesanthus Pierre}

\section{Marquesia acuminata (Gilg) R.E.Fr.}

Marquesia acuminata (Gilg) R.E.Fr. (1914a) 351. - Monotes acuminatus Gilg (1899) 136. - Type: Buchner 525 (holo B†?, n.v.), Angola, Malange, river Ruidu, Oct. 1880.

Marquesia noldeae Mildbr. (1939) 379. - Type: Nolde 717 (holo B†?, n.v.; iso COI, LISC), Angola, Quela, Apr. 1938.

Tree 15-20 m tall, with buttresses at the base of the trunk. Leaves $5-10$ by $2.5-4.5 \mathrm{~cm}$, lanceolate; rounded to slightly cordate and asymmetrical at the base, acuminate at the apex; lower surface glabrous except for some dispersed hairs on the midrib and lateral nerves; upper surface glabrous, often with two glands at the base, 8-10 pairs of lateral nerves; petiole 7-9 mm long. Inflorescences large terminal panicles, manyflowered. Fruits ovoid-conical, $6-8 \mathrm{~mm}$ diam; wings narrowly oblanceolate c. 20 by $5 \mathrm{~mm}$.

Ecology - Disperse in Brachystegia or mixed woodlands. Distribution - MA: Nolde 717 (LISC). - MO: Gossweiler 12503 (LISC). - UI: Raimundo, Matos \& Figueira 478 (LISC). Also in the Democratic Republic of the Congo and Zambia.

\section{Marquesia macroura Gilg}

Marquesia macroura Gilg (1908a) 485. - Type: Marques 172 (holo B†?, n.v.; iso COI), Angola, Malange, Ma-Chingue, June 1885.

Monotes sapinii De Wild. (1927) 180. - Syntypes: Sapin 30 (BR, seen in JSTOR), June 1908; Delevoy 7 (BR, seen in JSTOR), 14 Feb. 1921, 926 (BR, seen in JSTOR) June 1922, 974 (BR, seen in JSTOR) 29 July 1922. All from Democratic Republic of the Congo.

Tree up to $30 \mathrm{~m}$ tall, buttressed at the base. Leaves $6-12$ by $2.5-3.5 \mathrm{~cm}$, narrowly lanceolate; acuminate at the apex, rounded to slightly cordate at the base upper surface glabrous, with a single gland at the base; lower surface of leaf blade of adult leaves with a short and dense indumentum, 10-14 pairs of lateral nerves; petiole 1.4-1.6 cm long. Inflorescences axillary, panicles, with small whitish flowers. Fruits ovoid-conical, 4-6 $\mathrm{mm}$ diam; wings narrowly elliptic c. 15 by $4 \mathrm{~mm}$.

Ecology - Common and often dominant in woodlands in Kalahari sands; altitude 800-1200 m.

Distribution - BE: Raimundo, Matos \& Figueira 1314 (LISC). - BI: Monteiro \& Murta 1519, 1553, 1753, 1874, 1879, 2042 (LISC); Santos 1723 (LISC). - LS: Carrisso \& Mendonça 283 (COI); Gossweiler 11534, 11567, 11792 (LISC); Machado ANG. VII.54-197 (LISC); Sanjinje ANG.VII.54-211 (LISC). - MA: Barbosa, Moreno \& Sousa 11911 (LISC); Marques 172 (COI); Menezes 2629 (LISC). - MO: Almeida 554-FI. (LISC); Araújo 110 (LISC); Gossweiler 12258, 13087 (LISC); Teixeira \& Pedro 7601 (LISC). - UI: Raimundo, Matos \& Maia 847 (LISC). Also in Zimbabwe, the Democratic Republic of the Congo and Tanzania.

Vernacular names - muvuca (Monteiro \& Murta 1874), unjica (Monteiro \& Murta 2042), mundoca (Menezes 2629), mizica, mujica (Almeida 554-FI.)

\section{Monotes A.DC}

\section{Monotes adenophyllus subsp. delevoyi (De Wild.) P.A.Duvign.}

Monotes adenophyllus subsp. delevoyi (De Wild.) P.A.Duvign. (1959) 101. - Type: Delevoy 524 (holo BR, seen in JSTOR), Democratic Republic of the Congo, Masolwa, 17 Dec. 1921.

Monotes delevoyi De Wild. (1927) 171. - Type as above.
Shrub or small tree up to $8 \mathrm{~m}$ tall. Leaves $7-16$ by $5-13 \mathrm{~cm}$, broadly ovate to suborbicular, rounded to slightly emarginate at the apex, truncate to cordate at the base; upper surface finely reticulate, with straight hairs more abundant on the midrib and lateral nerves; lower surface with simple and penicillate hairs on the nerves and veins, areoles glabrous; midrib, lateral nerves and veins impressed in the upper surface prominent on the lower surface, lateral nerves in 10-13 pairs; petiole 10-20 $\mathrm{mm}$ long. Inflorescences axillary $2-5 \mathrm{~cm}$ long. Flowers with sepals $2.5-3.5 \mathrm{~mm}$ long, petals $8-9 \mathrm{~mm}$ long, both tomentose, anthers with a long triangular or oblong appendage at the apex. Fruits 1.2-1.4 cm diam, globose, mucronate at the apex; wings lanceolate to broadly lanceolate, $2.5-4$ by $1.5-2.5 \mathrm{~cm}$.

Ecology - In Brachystegia woodlands and shrublands.

Distribution - HI: Correia 3389 (LISC); Santos 778 (LISC); Torre 8819 (LISC). - NA: Teixeira \& Andrade 4487 (LISC). Also in the Democratic Republic of the Congo (Katanga) and in Zambia.

Vernacular name - munthêancába (Teixeira \& Andrade 4487).

\section{Monotes adenophyllus subsp. homblei (De Wild.) P.A.Duvign.}

Monotes homblei De Wild. (1915) 55. - Monotes magnificus var. homblei (De Wild.) P.A.Duvign. (1949) 55. - Monotes adenophyllus subsp. homblei (De Wild.) P.A.Duvign. (1959) 102. - Syntypes: Homblé 1177 (BR, seen in JSTOR), 1249 (BR, seen in JSTOR; K), Democratic Republic of the Congo, Kapiri Valley, Feb. 1913.

Small tree up to $8 \mathrm{~m}$ tall. Leaves $6-11$ by $4-9 \mathrm{~cm}$, broadly elliptic-oblong to orbicular, truncate to emarginate at the apex, cordate to truncate at the base; upper surface brownish in the dried specimens, finely reticulate, with the midrib, lateral nerves and veins depressed; with long, simple hairs more frequent on the nerves and veins; lower surface discolorous, greyish or whitish, with short penicillate hairs on the midrib and lateral nerves mixed with long curled hairs on the nerves and veins; interreticular areoles covered with stellate hairs; yellow to amber-coloured glands on the lower surface; lateral nerves in 10-12 pairs; petiole $10-20 \mathrm{~mm}$ long. Inflorescences axillary, $1-3 \mathrm{~cm}$ long, shortly pedunculate. Flowers with sepals $2.5-3.5$ $\mathrm{mm}$ long, petals $8-9 \mathrm{~mm}$ long, both tomentose; anthers with a long triangular or oblong appendage at the apex. Fruits subglobose 1-1.4 cm diam, mucronate at the apex; wings narrowly elliptic to narrowly oblong, $4-5$ by $1.2-1.8 \mathrm{~cm}$.

Ecology — In woodland and subxerophytic forest; altitude c. $1200 \mathrm{~m}$

Distribution - BE: Gossweiler 2934b (COI). - LS: Exell \& Mendonça 1399, 1400, 1401 (COI, LISC). - MA: Santos 1369 (LISC). - MO: Machado ANG.I.55-230, ANG.I.55-241 (LISC); Monteiro, Santos \& Murta 518, 522 (LISC). Also in the Democratic Republic of the Congo (Katanga) and in Zambia.

\section{Monotes africanus A.DC.}

Monotes africanus A.DC. (1868) 624. - Vatica africana (A.DC.) Welw. (1869) 15. - Type: Welwitsch 1035 (holo LISU; iso P, PRE), Angola, Huila, Lopolo, 1860.

Shrub or small tree up to $10 \mathrm{~m}$ tall. Leaves $4-10$ by $2-5.5 \mathrm{~cm}$, elliptic to oblong or obovate, obtuse to emarginate at the apex, rounded to slightly cordate at the base; upper surface finely reticulate, glabrous except on the midrib and lateral nerves of young leaves; lower surface with the interreticular areoles glabrous and the midrib, lateral nerves and veins with curled hairs, more abundant in the young leaves and becoming glabrescent in the mature ones, 8-13 pairs of lateral nerves, petiole 8-18 $\mathrm{mm}$. Inflorescences axillary, few-flowered, 1.5-3 $\mathrm{cm}$ long. Flowers with sepals $2-3 \mathrm{~mm}$ long, petals $8-10 \mathrm{~mm}$ 
long, both tomentose; anthers with a large triangular or emarginate appendage at the apex. Fruits subglobose, $0.8-1.2 \mathrm{~cm}$ diam, rounded to conical at the apex, sericeous; wings elliptic to narrowly obovate, $2-3.5$ by $0.8-1.6 \mathrm{~cm}$.

Ecology - Common in Brachystegia woodland on sandy soils; also in valley bottoms and river margins; altitude 350$1800 \mathrm{~m}$.

Distribution - BI: Baum 652 (COI); Gossweiler 3997 (LISC). - CC: Almeida 424-FI (LISC); Dechamps, Murta \& Silva 1340 (LISC); Mendes 2319, 2408, 2474, 2601, 2945, 2953 (LISC); Santos 2056, 2514 (LISC); Teixeira 4 (COI, LISC). - CU: Menezes, Barroso \& Sousa 4544 (LISC). - HA: Barbosa \& Correia 8890 (LISC); Exell \& Mendonça 1848 (COI, LISC); Silva 3318 (LISC); Santos 1324 (LISC). - HI: Antunes vel Dekindt 633 (LISC); Barbosa 9709 (LISC); Gossweiler 13211 (LISC); Mendes 801, 1915 (LISC); Menezes 1267, 1595, 1834, 3224 (LISC); Santos 592 (LISU); Teixeira 1828 (LISC); Welwitsch 1035 (LISU). - LS: Exell \& Mendonça 1191, 1405 (COI, LISC). Also in the Democratic Republic of the Congo, Malawi, Mozambique, Tanzania and Zambia.

Vernacular names - omufui (Antunes vel Dekindt 633), mufui (Menezes 1595), mussénêne (ganguela, Teixeira 4).

Note - The amount of indumentum in the lower surface of leaves is quite variable in this species; in most specimens observed the veins and nerves are covered with abundant curled hairs, although some specimen have sparse hairs and a few ones are almost glabrous in both surfaces. This seems to be related to the maturity state of leaves or to local environmental conditions.

\section{Monotes angolensis De Wild.}

Monotes angolensis De Wild. (1927) 168. - Syntypes: Delevoy 502 (BR, seen in JSTOR), Democratic Republic of the Congo, 12 Dec. 1921; Delevoy 523 (BR, seen in JSTOR), Democratic Republic of the Congo, 21 Dec. 1921; Gossweiler 2893 (BM, BR, COI, K, LISC), Angola, Huila, Ganguelas, Feb. 1907; 2910 (BM, BR, COI, K, LISC) Angola, Huila, Dongo, Forte Maria Pia, 8 Feb. 1907.

Monotes oblongifolius Hutch. (1931) 248. - Type: Hutchinson \& Gillet 3765 (holo K, seen in JSTOR), Zambia, Kaloswe, 16 July 1930.

Small tree up to $12 \mathrm{~m}$ tall, or shrub. Leaves $5-8(-10)$ by $2-4(-5)$ $\mathrm{cm}$, elliptic to obovate, discolor, obtuse, rounded, or slightly emarginate at the apex, rounded to cordate at the base; upper surface brown-coloured, smooth, with short penicillate hairs, more abundant on the midrib and lateral nerves; lower surface yellowish to brownish, tomentose, with straight and stellate hairs on the nerves, and dense minute hairs covering the interreticular areoles, lateral nerves in 11-18 pairs, not reaching the margin; petiole 1.1-2.2 cm long, canaliculate. Inflorescences axillary, few-flowered, up to $2.5 \mathrm{~cm}$ long. Flowers with sepals c. 2-3 $\mathrm{mm}$ long, petals 5-6 long, both tomentellous; anthers with a triangular appendage at the apex. Fruits subglobose, $1-1.2 \mathrm{~cm}$ diam; wings lanceolate, $2.5-5$ by $0.6-1.2 \mathrm{~cm}$.

Ecology - In Brachystegia woodlands and savanna woodlands; altitude 1500-1800 m.

Distribution - BE: Carrisso \& Sousa 89 (LISC). - BI: Dechamps, Murta \& Silva 1383 (LISC); Gossweiler 2893, 2910 (COI, LISC), 3945, 3945b (LISC). - CC: Mendes 2649 (LISC). CU: Silva 3052 (LISC). - HA: Dechamps, Murta \& Silva 1014, 1056 (LISC); Gossweiler 9663 (COI); Silva 2003 (LISC), 3673 (COI); Teixeira \& Sousa 6444 (LISC). - HI: Mendonça 4605B (LISC); Santos 775 (LISC); Torre 8542 (LISC); Welwitsch 1077 (LISU). - MA: Dechamps, Murta \& Silva 1420 (LISC). - MO: Barbosa 11068 (LISC). Also in the Democratic Republic of the Congo and Zambia.

Vernacular name - osuim-da-anhara (Teixeira \& Sousa 6444).
Note - The dimensions of leaf blades and petioles of some of the specimens identified as M. angolensis (e.g. Dechamps, Murta \& Silva 1014, 1383) fall outside the ranges referred to by De Wildeman in the protologue of this species. Nevertheless, those specimens match the remaining characteristics of the species and it is known that juvenile plants can have leaves larger than mature ones. In addition, both Bancroft (1937) for Angola, and Duvigneau (1961) for the Flora Zambesiaca area, referred to larger leaf dimensions for this species than those cited in the protologue.

\section{Monotes caloneurus Gilg}

Monotes caloneurus Gilg (1899) 136. - Syntypes: Buchner 159 (B†?, n.v.), Angola, Malange, Jan. 1880; Buchner 524 (B†?, n.v.), Angola, Malange, April 1880; Mechow 434 (B十?, n.v.), Angola, Malange, Jan. 1880; Mechow 455 (B十?, n.v.; W, seen in JSTOR), Angola, Malange, March 1880; Schweinfurth 2678 (B†?, n.v.; K, seen in JSTOR), Central Africa, 17 Nov. 1869.

Small tree up to $10 \mathrm{~m}$ tall, or shrub. Leaves $10-15(-20)$ by $5-8(-11) \mathrm{cm}$, oblong-elliptic to ovate-oblong, rounded to emarginate at the apex, rounded to cordate at the base; upper surface glabrous in mature leaves, except for the midrib which can maintain straight hairs; basal gland elliptical; lower surface yellowish to brownish, tomentose in young leaves, less dense with age, with curled hairs on the veins and minute, dense stellate hairs covering the interreticular areoles, lateral nerves 12-16 pairs, prominent in the lower surface, brown-coloured; petiole robust, $1.4-2.5 \mathrm{~cm}$ long. Inflorescences axillary, 5-7 $\mathrm{cm}$ long, with numerous flowers. Flowers with sepals c. $3 \mathrm{~mm}$ long, tomentose, petals $6-8 \mathrm{~mm}$ long, sericeous, anthers with a long triangular appendage at the apex. Fruits globose c. $1 \mathrm{~cm}$ diam; wings $4-5$ by $1.5-2.5 \mathrm{~cm}$, elliptical to obovate.

Ecology - In subxerophilous forest; altitude up to $1300 \mathrm{~m}$.

Distribution - BE: Dechamps, Murta \& Silva 1069 (LISC). BI: Cardoso s.n. (LISC); Dechamps, Murta \& Silva 1389 (LISC); Monteiro \& Murta 1846 (LISC). - CN: Teixeira et al. 12102 (LISC). - CS: Exell \& Mendonça 3077 (COI); Raimundo, Matos \& Figueira 681A (LISC); Santos 1309, 1313 (LISC). - HA: Dechamps, Murta \& Silva 1069 (LISC); Gossweiler 9965 (COI, LISC); Henriques 890 (LISC, LISU); Silva 3442 (LISC). - MA: Exell \& Mendonça 109 (LISC); Gouveia 1476 (LISC); Santos 1369 (LISC). Also in the Democratic Republic of the Congo and Zambia.

Note - Duvigneaud (1949) distinguishes variety dawei (H.H.Bancr.) H.H.Bancr. and the form cordatus (Hutch.) P.A. Duvign., but these taxa were not accepted widely and we see no necessity to distinguish subspecific taxa in this species.

\section{Monotes carrissoanus H.H.Bancr.}

Monotes carrissoanus H.H.Bancr. (1939b) 110. - Type: Exell \& Mendonça 1788 (holo BM, seen in JSTOR; iso COI), Angola, Moxico, between Caxipoque and Munhango, 7 May 1937.

Tree $10-15 \mathrm{~m}$ tall. Leaves $6-9$ by $3-5 \mathrm{~cm}$, elliptic, rounded to obtuse at the apex, rounded to acute at the base, often mucronate; upper surface with simple and glandular hairs, more abundant in the midrib and lateral nerves; lower surface covered with a short indumentum of curled hairs, covering but not masking the reticulation, with 10-13 pairs of lateral nerves; petioles $2-3 \mathrm{~cm}$ long, canaliculate. Flowers not seen. Fruits subglobose $0.8-1 \mathrm{~cm}$ diam; wings $2.5-3.5$ by $0.5-1 \mathrm{~cm}$, narrowly lanceolate.

Ecology - In dry forest; altitude 1200-1500 m.

Distribution - Endemic to the north-east of Angola. - MO: Exell \& Mendonça 1788 (COI); Gossweiler 11311 (BM, COI).

Conservation status - The species is known only from two collections made during the same expedition and no other 
collections events are known for that locality. It should be considered as Data Deficient with insufficient information (DD 3).

Note - This is a poorly known species, from which only the specimens cited in the protologue are known. However, these specimens are in a good condition and no further material was observed that matched the species description and the type material.

\section{Monotes dasyanthus Gilg}

Monotes dasyanthus Gilg (1903) 307. - Type: Baum 888 (holo B†?, n.v.; iso $\mathrm{BM}, \mathrm{COI}, \mathrm{HBG}, \mathrm{K}, \mathrm{M}, \mathrm{W})$, Angola, Cuando-Cubango, 2 May 1900.

Small tree $4-10 \mathrm{~m}$ tall. Leaves $7-13$ by $4-7(-10) \mathrm{cm}$, ovate, broadly ovate or obovate; acute, obtuse, acuminate, rounded or emarginate at the apex, rounded to cordate at the base; basal gland ovate to rounded; midrib and lateral nerves impressed in the upper surface and prominent beneath; upper surface dark green or brown-coloured, scaberulous, covered with simple straight hairs; lower surface discolor, fulvous, tomentose, with flexuous hairs in the nerves and veins, masking the interreticular areoles, lined by stellate hairs and disperse yellow to amber glands, $10-15$ pairs of lateral nerves; petiole $1.4-2.2 \mathrm{~cm}$ long. Inflorescences subsessile terminal panicles, many-flowered, $3-6 \mathrm{~cm}$ long. Flowers with sepals $3 \mathrm{~mm}$ long, petals $8 \mathrm{~mm}$ long, both densely sericeous-tomentose, anthers not produced at the apex. Fruits subglobose, $0.8-1 \mathrm{~cm}$ diam, conical at the apex; wings obovate to spatulate $2-4$ by $1-1.5 \mathrm{~cm}$.

Ecology - Very common on Kalahari sands, at the edges of forests and in xerophilous scrub; altitude 1200-1300 m in Angola.

Distribution - BE: Carrisso \& Sousa 90 (LISC); Gossweiler 12376 (LISC). - BI: Barbosa 12123 (LISC); Barbosa \& Moreno 12367 (LISC); Exell \& Mendonça 1760 (LISC); Gossweiler 2976, 3172 (LISC), 3856 (COI); Monteiro \& Murta 1538 (COI, LISC); Santos 1708 (COI, LISC). - CC: Dechamps, Murta \& Silva 1358 (LISC); Mendes 3099 (LISC); Santos 2084, 2307, 2317 (LISC). - HA: Andrada 54 (LISC, LISU); Dechamps, Murta \& Silva 1015(LISC); Gossweiler 12371 (LISC); Henriques 1370 (LISC, LISU). - HI: Menezes 1836 (LISC). Also in the Democratic Republic of the Congo and Zambia.

Vernacular name - tchipalameia (Monteiro \& Murta 1538).

Note - This species has similarities with $M$. mutetetwa in the shape of leaf blade and indumentum of leaves, but the leaves of $M$. dasyanthus are in general smaller. Another distinction is its area of occurrence. Monotes dasyanthus occurs in central and southern Angola, Zambia and Western Katanga, whereas M. mutetetwa occurs in the north of Angola and the south-east of the Democratic Republic of the Congo.

\section{Monotes dawei H.H.Bancr.}

Monotes dawei H.H.Bancr. (1936a) 43. - Type: Dawe 324 (holo K, seen in JSTOR), Angola, Bié, Libolo, Longa river, Dec. 1921.

Tree $10-15 \mathrm{~m}$ tall. Leaves $8.5-13$ by $4-7 \mathrm{~cm}$, elliptical to obovate-elliptical; rounded to slightly emarginate at the apex, rounded at the base; upper surface with stellate and simple hairs, basal gland elliptical; lower surface with a dense indumentum of short curled hairs, less dense in the areoles, 14-18 pairs of lateral nerves; petiole 1.1-1.7 cm long. Inflorescences axillary $4-5.5 \mathrm{~cm}$ long. Flowers with sepals c. $4 \mathrm{~mm}$ long, tomentellous, petals c. $10 \mathrm{~mm}$ long, anthers with a short triangular appendage at the apex. Fruits c. $1 \mathrm{~cm}$ diam; wings elliptical $2-3.5$ by $1.1-1.8 \mathrm{~cm}$.

Ecology - In dry forest; altitude 1200-1500 m.

Distribution - Endemic to the south-east of Angola. - CC: Baum 925 (COI); Dawe 324 (K).
Conservation status - The species is known from two collections only. As no other collections are known from the same locality, it should be considered as Data Deficient with insufficient information (DD 3).

Note - This is a poorly known species, only the specimens cited in the protologue being known. Comparing the specimen Baum 925 to specimens of the nearest species, M. caloneurus, the distinctive characters referred by Bancroft (1936a) are consistent. So, even though it is poorly known, $M$. dawei must be maintained as a species.

\section{Monotes discolor R.E.Fr.}

Monotes discolor R.E.Fr. (1914b) 153. - Type: Fries 1175 (holo S, n.v.; iso UPS, n.v.), Zambia, Mporokoso, 31 Oct. 1911.

Shrub or small tree up to $6 \mathrm{~m}$ tall. Leaves $11-20(-25)$ by $7-$ $12(-16) \mathrm{cm}$, broadly elliptic to obovate or suborbicular, discolor; cordate to rounded at the base, rounded, truncate or emarginate at the apex; basal gland rounded to obovate; upper surface green coloured, glabrous in adult leaves except for the midrib, with disperse straight hairs; lower surface whitish, tomentose, with sparse straight hairs and yellow glands on the nerves and dense, short curled hairs covering the veins and interreticular areoles, lateral nerves $14-18$ pairs, not reaching the leaf margin; petiole robust, $1.5-3.5 \mathrm{~cm}$ long. Inflorescences axillary, few-flowered. Flowers with sepals $4-5 \mathrm{~mm}$ long, petals c. $10 \mathrm{~mm}$ long, both tomentose, anthers with a long triangular appendage at the apex. Fruits globose $1-2.5 \mathrm{~cm}$ diam; wings lanceolate, narrowly obovate or spathulate $3-5.5$ by $1-2 \mathrm{~cm}$.

Ecology - In Brachystegia woodlands and savanna woodlands; altitude 1200-1800 m.

Distribution - BI: Bamps, Martins \& Maia 4196 (LISC); Cardoso s.n. (COI, LISC); Gomes \& Silva 2812 (LISC); Gossweiler 3528 (COI, LISC), 3528b (LISC). - CS: Teixeira et al. 7424 (LISC). - HA: Barbosa 10924, 11007, 11581, 11851 (LISC); Barbosa \& Correia 8892 (LISC); Dechamps, Murta \& Silva 1016 (LISC); Exell \& Mendonça 1687 (COI, LISC); Mendes 560, 2167 (LISC); Murta 115 (LISC); Santos 896 (LISC, LISU); Silva 2849 (LISC); Teixeira \& Sousa 6443 (LISC). - HI: Gossweiler 11312 (COI). - LS: Exell \& Mendonça 295 (COI). Recorded also from Zambia, Democratic Republic of the Congo and Malawi.

Vernacular names - m'popoca (Gossweiler 3528b), ossuim (Barbosa 11581), quimbuetebuete (Teixeira 7424), suim (quimbundo, Mendes 2167).

Note - Duvigneaud (1961) accepts three varieties in M. discolor (the type variety, var. lanatus and var. cordatus). All Angolan specimens observed fall into the type variety.

\section{Monotes elegans Gilg}

Monotes elegans Gilg (1908b) 291. — Type: Holtz 1474 (holo B†?, n.v.), Tanzania, Tabora, s.d.

Tree up to $10 \mathrm{~m}$ tall, or shrub. Leaves $8-11$ by $4.5-7 \mathrm{~cm}$, elliptic to oblong or obovate-oblong, rounded to cordate at the base, rounded to cordate at the apex, upper surface glabrous or with some remaining hairs and yellow glands in the midrib and lateral nerves; lower surface discolorous, greyish to brownish, with an indumentum of short cottony hairs on the nerves and veins, interreticular areoles covered with minute stellate hairs, 12-16 pairs of lateral nerves; petiole slender, $10-15 \mathrm{~mm}$ long. Inflorescences axillary, many-flowered, up to $6 \mathrm{~cm}$ long. Flowers with sepals c. $3 \mathrm{~mm}$ long, petals c. $10 \mathrm{~mm}$ long, anthers with a rounded appendage at the apex. Fruits subglobose, $1-1.5 \mathrm{~cm}$ diam; wings variable in shape and size but commonly narrowly elliptical to broadly elliptical, $2.5-4$ by $1-2 \mathrm{~cm}$. 
Ecology - In subxerophytic woodland; altitude of $1200-$ $1300 \mathrm{~m}$.

Distribution - BI: Barbosa 11341 (LISC); Barbosa \& Moreno 12237 (LISC); Exell \& Mendonça 1744 (COI). - LS: Exell \& Mendonça 1228 (COI, LISC). Also in the Democratic Republic of the Congo, Tanzania, Zambia and Zimbabwe.

Note - As referred by Bancroft (1939a), M. elegans is a very variable species with close affinities to $M$. caloneurus and M. hypoleucus.

\section{Monotes engleri Gilg}

Monotes engleri Gilg (1908b) 291. — Type: Engler 3159 (holo B†?, n.v.), Zimbabwe, near Mutare, s.d.

Monotes tomentellus Hutch. \& Milne-Redh. in Hutch. (1931) 248. — Type: Teague 431 (holo K, seen in JSTOR), Zimbabwe, Odzani River Valley, 1915.

Shrub up to $4 \mathrm{~m}$ tall. Leaves $3-6$ by $2-3 \mathrm{~cm}$, elliptical to obovate, obtuse to rounded at the apex, rounded to subcordate at the base; upper surface glabrous, finely reticulate, somewhat shining, with numerous dotted glands, lower surface with the nerves and veins moderately prominent, covered with short curled hairs, areoles covered with stellate hairs, 9-12 pairs of lateral nerves; petiole 8-12 mm long. Inflorescences fewflowered, c. $3 \mathrm{~cm}$ long. Flowers with sepals $3 \mathrm{~mm}$ long, petals c. $10 \mathrm{~mm}$ long, both tomentose; stamens with a triangular appendage at the apex. Fruits subglobose, c. $1 \mathrm{~cm}$ diam; wings $3-4$ by $1-1.7 \mathrm{~cm}$, dark red in fresh condition.

Ecology — In savanna woodland on sandy soils.

Distribution - HI: Teixeira 910 (LISC).

Note - Angola was not included the distribution area of M. engleri (N Zambia, Zimbabwe, Malawi and Mozambique) (e.g. Duvigneaud 1961), but with the collection Teixeira 910 the presence in Angola can be established.

\section{Monotes glaber Sprague}

Monotes glaber Sprague (1909) 305. - Syntypes: Allen 734 (K, seen in JSTOR), Zimbabwe, valley of the Hanyani River, 17 May 1909; Baines s.n. (K, seen in JSTOR), 'South Africa Gold-fields', s.d.

Shrub or small tree up to $7 \mathrm{~m}$ tall in Angola (up to $20 \mathrm{~m}$ in the Flora Zambesiaca area). Leaves $5-9.5$ by $2-5 \mathrm{~cm}$, elliptic to oblong or obovate-oblong, rounded to cordate at the base, obtuse to truncate at the apex; midrib and lateral nerves slightly depressed above and prominent beneath; upper surface glabrous, shining, finely reticulate, lower surface glabrous, with the venation scarcely prominent, 8-11 pairs of lateral nerves; petiole $0.8-1.5 \mathrm{~cm}$. Inflorescences axillary, up to $4 \mathrm{~cm}$ long, fewflowered. Flowers with sepals $3 \mathrm{~mm}$ long, petals $7-8 \mathrm{~mm}$ long, anthers shortly mucronate at the apex. Fruits subglobose, $0.8-1$ $\mathrm{cm}$ diam; wings elliptic to narrowly obovate $2-3$ by $1-1.5 \mathrm{~cm}$.

Ecology — In woodland and savanna woodland; altitude $1150-1450 \mathrm{~m}$.

Distribution - BE: Andrada 93 (LISC, LISU). - BI: Andrada 42 (LISC, LISU); Monteiro \& Murta 1688, 1839 (LISC); Santos 1857 (LISC). - MA: Dechamps, Murta \& Silva 1475 (LISC). MO: Almeida 538:FI (LISC). Also in Botswana, Zambia and Zimbabwe.

Vernacular name - munhande (Almeida 538:Fl).

\section{Monotes gossweileri De Wild.}

Monotes gossweileri De Wild. (1927) 173. - Type: Gossweiler 3904 (holo $\mathrm{BR}$, seen in JSTOR; iso BM, COI, LISC), Angola, Bié, 13 Nov. 1906.

Undershrub, shrub or small tree up to $4 \mathrm{~m}$ tall. Leaves 4-9.5 by $1.5-5 \mathrm{~cm}$, ovate, obovate or elliptical; rounded to obtuse at the apex, obtuse, rounded or cordate at the base; upper surface shining, with a sparse indumentum of simple straight hairs; lower surface with the venation scarcely prominent and an indumentum of curled hairs on the nerves and veins, masking the interreticular areoles covered with stellate hairs, 7-11 pairs of lateral nerves; petiole 5-10 $\mathrm{mm}$. Inflorescences axillary, up to $5 \mathrm{~cm}$ long, few-flowered. Flowers with sepals c. $3 \mathrm{~mm}$ long, tomentose, petals c. $7 \mathrm{~mm}$ long, pilose, anthers not seen. Fruits globose, $0.8-1 \mathrm{~cm}$ diam; wings elliptic to narrowly obovate $2-3.5$ by $1-1.5 \mathrm{~cm}$.

Ecology - In xerophilous scrub on sandy ground; altitude 1200-1500 m.

Distribution - Endemic to Eastern Angola. - BI: Gossweiler 2778, 3904 (COI, LISC). - CC: Mendes 2441, 3112 (LISC). LS: Exell \& Mendonça 1192, 1226, 1424 (COI), 1445 (COI, LISC); Gossweiler 11410 (COI). - MO: Young 1380 (BM, n.v.).

Conservation status - The species is known from eight collections made in five different locations and can be considered as vulnerable by having a very small or restricted population (VU D2).

\section{Monotes hutchinsonianus Exell}

Monotes hutchinsonianus Exell (1932) 219. — Syntypes: Gossweiler 9581 (BM, COI, K, LISC), Angola, Malange, 27 Dec. 1930.

Shrub or tree. Leaves $9-14$ by $5-10 \mathrm{~cm}$, elliptical or obovateelliptical, rounded to cordate at the base, emarginate at the apex; with 10-12 pairs of lateral nerves; upper surface with a sparse indumentum of simple hairs; lower surface with the midrib and lateral nerves covered with penicillate and simple flexuous hairs, veins covered with flexuous hairs, interreticular areoles glabrous; petiole $1.8-2.5 \mathrm{~cm}$ long. Inflorescences axillary, up to $10 \mathrm{~cm}$ long, many-flowered. Flowers with sepals c. 3 $\mathrm{mm}$ long, stellate-tomentellous, petals c. $9 \mathrm{~mm}$ long, sericeous; anthers with a long triangular appendage at the apex. Fruits unknown.

Ecology - In open subxerophilous scrub; altitude $1000 \mathrm{~m}$.

Distribution - Endemic to northern Angola. - MA: Gossweiler 9581 (COI, LISC).

Conservation status - The species is only known from a single location. Since the same area was surveyed several times after the species was described, and there are no further collections known, it can be considered as rare. It should be classified as vulnerable by having a very small and restricted population (VU D2).

Note - This is a poorly known species, from which only the type is known. The leaves of this species share characters with M. adenophyllus subsp. delevoyi, but have a denser indumentum and the veins are more prominent in the lower surface.

\section{Monotes hypoleucus (Welw. ex Oliv.) Gilg}

Monotes hypoleucus (Welw. ex Oliv.) Gilg (1899) 134. - Vatica africana var hypoleuca Welw. ex Oliv. (1868) 173. - Type: Welwitsch 1036 (holo LISU, iso B, BM, BR, COI, K), Angola, Huíla, Humpata, Dec. 1859. Monotes kapiriensis De Wild. (1927) 175. — Type: Homblé 1228 (BR, seen in JSTOR), Democratic Republic of the Congo, Kapiri Valley, Feb. 1913.

Small tree or shrub. Leaves $7-10$ by $4-6 \mathrm{~cm}$, elliptical or obovate-elliptical, rounded at the base, rounded to emarginate at the apex, with 11-16 pairs of lateral nerves; upper surface dark in young condition, covered with stellate hairs, glabrescent with age; lower surface with a white-greyish indumentum of curled hairs covering the veins and nerves and disperse straight hairs in the nerves; petiole $1.5-2 \mathrm{~cm}$ long, terete. Inflorescences axillary, few-flowered. Flowers with sepals c. 3 $\mathrm{mm}$ long, petals c. $9 \mathrm{~mm}$ long, both tomentose, anthers with a triangular appendage at the apex. Fruits subglobose, c. $1.5 \mathrm{~cm}$ diam; wings lanceolate to broadly elliptical $4-5$ by $1.5-2.5 \mathrm{~cm}$.

Ecology — In xerophilous forest or scrub, in sandy soils. 
Distribution - BE: Gossweiler 1804 (COI, LISC). - BI: Gossweiler 2934 (COI), 3943 (COI, LISC). - HI: Welwitsch 1036 (COI, LISU). Also in the Democratic Republic of the Congo. Bancroft (1937) refers to this species as occurring also in Zimbabwe and Tanzania, but that occurrence was not confirmed by Duvigneaud (1961) and Verdcourt (1989).

\section{Monotes loandensis Exell}

Monotes loandensis Exell (1932) 220. - Type: Gossweiler 9492 (holo BM, seen in JSTOR; iso COI, K, LISC ex LISJC), Angola, Malange, Quirima, 23 Jan. 1931.

Shrub or tree up to $10 \mathrm{~m}$ tall. Leaves $6-8$ by $2-3 \mathrm{~cm}$, narrowly obovate or spatulate; rounded to emarginate at the apex, obtuse at the base, upper surface glabrous, except for the midrib and lateral nerves of young leaves, with some straight hairs; lower surface with the midrib and lateral nerves prominent, with dispersed straight hairs; interreticular areoles with a dense, short whitish indumentum of curled hairs, 11-12 pairs of lateral nerves; petiole $1.2-1.6 \mathrm{~cm}$. Inflorescences axillary, up to $4 \mathrm{~cm}$ long, few-flowered. Flowers with sepals c. $3 \mathrm{~mm}$ long, tomentellous, petals $8-9 \mathrm{~mm}$ long, sericeous, anthers with a triangular appendage. Fruits not seen.

Ecology - In subxerophilous vegetation and dry forest.

Distribution - Endemic to central Angola. - BI: Monteiro \& Murta 2038 (LISC). - HA: Barbosa 12265 (LISC). - MA: Gossweiler 9492 (COI, LISC).

Conservation status - The species is known from three collections and three different localities. Two of these locations were surveyed several times after the species description, but no further collections are known. With less than $12 \mathrm{~km}^{2}$ of known area of occupancy and just three locations $M$. loandensis can be considered as vulnerable by having a very small and restricted population (VU D2).

Vernacular names — ossui (Monteiro \& Murta 2038); ossuím (Barbosa 12265).

\section{Monotes mutetetwa P.A.Duvign.}

Monotes mutetetwa P.A.Duvign. (1949) 58. — Syntypes: Duvigneaud 840 M (BR, seen in JSTOR), Democratic Republic of the Congo, Kenge, 6 May 1948; Duvigneaud 954 M (BR, seen in JSTOR), Democratic Republic of the Congo, Kahemba, 1948.

Shrub or small tree up to $6 \mathrm{~m}$ tall in Angola (8-15 m elsewhere, Duvigneaud 1949). Leaves $8-15$ by $5-12 \mathrm{~cm}$, broadly elliptical, ovate or oblong; rounded to cordate at the base, typically acuminate at the apex, but often rounded to slightly emarginate, upper surface with an indumentum of simple hairs, lower surface with the nerves and veins prominent, tomentose, with flexuous hairs in the nerves and veins, not masking the interreticular areoles, which are covered with stellate hairs mixed with yellow glands, $14-18$ pairs of lateral nerves; petiole $1-2 \mathrm{~cm}$ long. Inflorescences condensed, 3-6 cm long, multi-flowered. Flowers with sepals $2-3 \mathrm{~mm}$ long, sericeous, petals $5 \mathrm{~mm}$ long, sericeous-pilose, anthers shortly mucronate. Fruits subglobose, conical at the apex, c. $1 \mathrm{~cm}$ diam; wings narrowly obovate $2-3$ by $1-1.5 \mathrm{~cm}$.

Ecology - In Isoberlinia-Brachystegia woodlands, and in subxerophytic bushland; altitude 1200-1300 m.

Distribution - LN: Machado ANG.VI.54-40 (LISC). - LS: Exell \& Mendonça 1154 (COI, LISC), 1155, 1223 (COI), 1230, 1404, 1517 (LISC); Gossweiler 11394, 11609, 11737 (LISC), 11544 (COI, LISC). - MO: Almeida 537:FI., 539:FI. (LISC); Exell \& Mendonça 1517, 1638 (COI, LISC); Monteiro, Santos \& Murta 509, 510 (LISC); Teixeira \& Pedro 7577 (LISC). Also in the Democratic Republic of the Congo.

Vernacular name - mubalangongo (Almeida 539:Fl.).
Note - Monotes mutetetwa has affinities with $M$. dasyanthus, see note under this species.

\section{Monotes noldeae H.H.Bancr.}

Monotes noldeae H.H.Bancr. (1936b) 226. - Type: Nolde 202 (holo B†?, n.v.; iso LISC), Angola, Malange, Apr. 1933.

Small tree. Leaves $4-7$ by $1.5-3 \mathrm{~cm}$, elliptical to obovate, rounded to emarginate at the apex, rounded to subacute at the base, upper surface glabrous, shining, lower surface tomentose, with simple, short hairs on the veins and interreticular areoles, with the lateral nerves prominent, $10-13$ pairs of lateral nerves; petiole 1.4-1.7(-2.2) cm long. Inflorescences axillary, 2-4 cm long, few-flowered. Flowers with sepals c. $2 \mathrm{~mm}$ long, densely pubescent, petals c. $7 \mathrm{~mm}$ long, pubescent, anthers with a narrowly triangular to subquadrate or bilobed appendage at the apex. Fruits subglobose, conical at the apex, $6-8 \mathrm{~mm}$ diam; wings lanceolate $20-30$ by $5-8 \mathrm{~mm}$.

Ecology - In xerophilous woodland, not common.

Distribution - Endemic to Malange province, Angola. - MA: Gossweiler 9520 (COI, LISC); Nolde 202 (LISC).

Conservation status - The species is known only from two collections, even though several collecting events took place in the same locality after its description. With less than $8 \mathrm{~km}^{2}$ of known area of occupancy and just two localities, $M$. noldae is rare and it should be considered as vulnerable by having a very small and restricted population (VU D2).

Vernacular name - m'basa basa (Gossweiler 9520).

\section{Monotes paivae L.Catarino \& E.S.Martins, sp. nov. - Fig. 1}

Monotes caloneuri affinis sed indumento persistente integrae paginae superioris foliorum (nec glabra foliis maturis propter costam) et lanato-tomentoso paginae inferioris maturorum foliorum (nec glabrescente) occultante areolas interreticulares differt. - Typus: Monteiro \& Murta 1919 (holo LISC; iso LISC LUA), Angola, Bié, Cuemba, Cachingues, c. 1300 m, 17 Sept. 1966 (fl).

Etymology. The specimens Monteiro \& Murta 1917 and 1919 were already identified as belonging to a probable new species close to $M$. caloneurus by Jorge Paiva in 1968. The name of the new species intends to be a tribute to his work in the African flora.

Small tree up to $7 \mathrm{~m}$ tall, with bole of 2-3 $\mathrm{m}$. Young shoots densely covered with simple and stellate hairs, glabrescent with age. Leaves alternate, simple, entire, $8-15$ by $5-10 \mathrm{~cm}$; leaf blade discolor, obovate to broadly elliptical, emarginate or rarely rounded at the apex, rounded, truncate or slightly cordate at the base; upper surface pubescent, with simple spreading hairs and stellate hairs, more abundant on the nerves of the basal part of the leaf blade, secondary and tertiary nerves impressed; lower surface with a continuous woolly-tomentose indumentum, midrib and lateral nerves prominent, brown-reddish; midrib with abundant fulvous stellate hairs and dispersed greyish bristles; lateral nerves with simple curled hairs, stellate hairs and rare bristles; veins densely covered with simple, curled hairs, hiding the interreticular areoles covered with short stellate hairs; basal gland broadly elliptical to obovate, $2-2.5 \mathrm{~mm}$ in length, $11-13$ pairs of lateral nerves; petiole almost terete to slightly canaliculate in the upper surface, $1.5-2.5 \mathrm{~cm}$ in length and $1.5-2.5 \mathrm{~mm}$ diam, with dense stellate hairs and greyish bristles dispersed. Flowers in axillary panicles of 10-20 flowers, with short peduncle and rachis covered with penicillate hairs. Sepals 5 , ovate, c. $3-4$ by $2 \mathrm{~mm}$, sericeous, acrescent; petals 5 , lanceolate, $10-12$ by $3-4 \mathrm{~mm}$, external surface densely sericeous; ovary ovoid, c. $3.5 \mathrm{~mm}$ in length; stamens numerous, anthers c. $0.6 \mathrm{~mm}$ long, with a triangular appendix c. $0.4 \mathrm{~cm}$ long, at the apex. Fruits globose, 8-12 mm diam, sericeous; wings 25-45 by $10-18 \mathrm{~mm}$, narrowly obovate to elliptical, rounded to obtuse at the apex, yellow-brownish to reddish in vivo, light brown when 


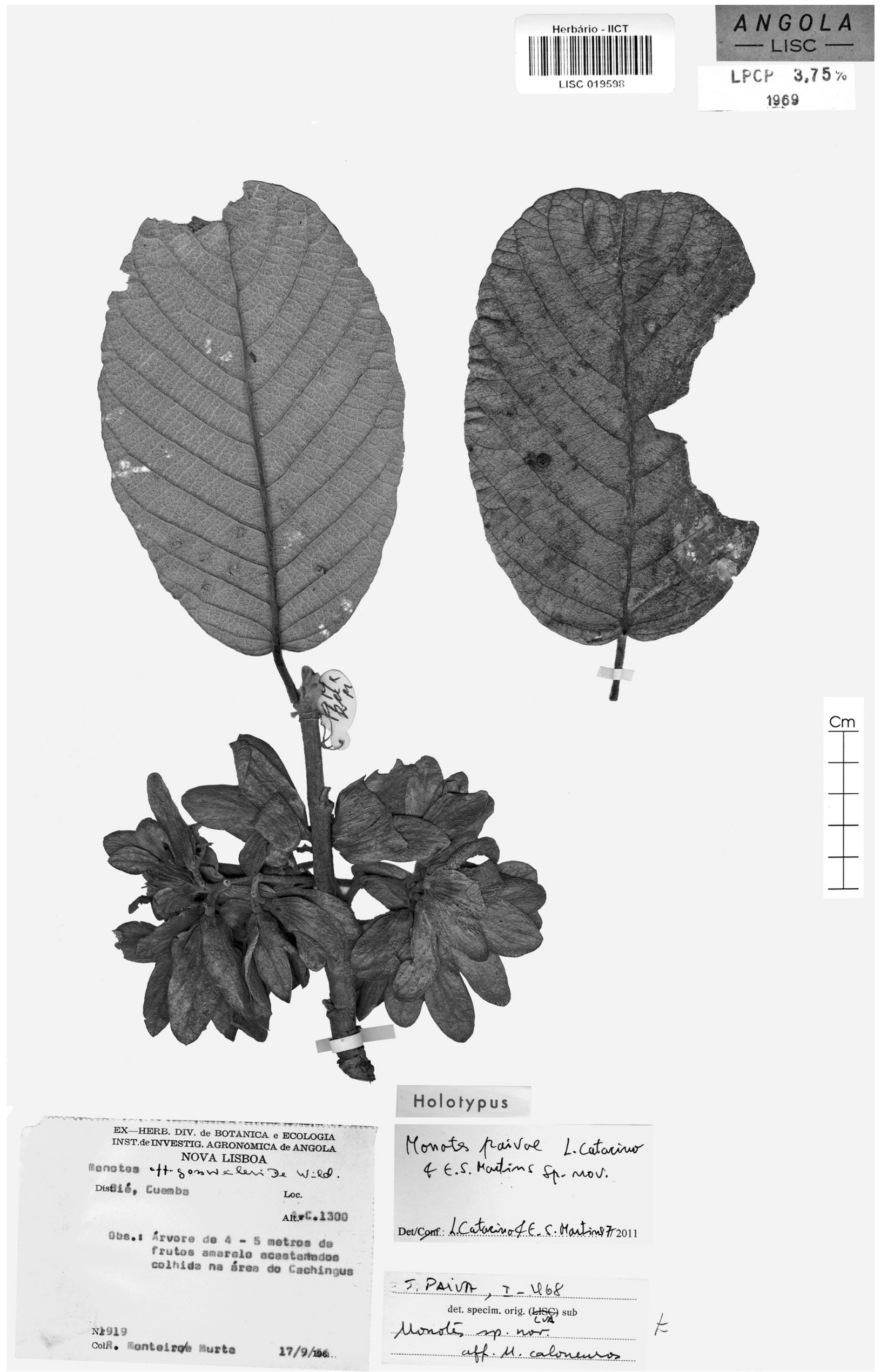

Fig. 1 Monotes paivae L.Catarino \& E.S.Martins. Flowering branch (Monteiro \& Murta 1919, holo LISC). 
dry, with the veins darker; stellate hairs and penicillate hairs more dense at the lower part of the external surface.

Ecology - Dispersed and little abundant in woodlands; altitude 1300-1600 m.

Distribution - Endemic to the Bié province, central Angola.

Phenology - Specimens with flowers collected in February and March, and with fruits collected in September and December.

Conservation status - Monotes paivae is known from nine collections made in five different locations. In the labels of three of the collections, this species is considered locally abundant, but its presence in only five locations within a restricted area makes it eligible to be considered as vulnerable by having a very small and restricted population (VU D2).

Additional specimens examined. ANGoLA, BI: Barbosa 12111 (LISC), at 5 km from Cachingues to Chitembo, 7 Apr. 1971; 12176 (LISC), between the road crossing Bié - Menongue and Chinguar, 11 Apr. 1971; Dechamps, Murta \& Silva 1382 (BR, LISC, LUA, MAD), near Bié, S12 ${ }^{\circ} 5^{\prime}$ E1659', alt. 1640 m, 7 Mar. 1974; Exell \& Mendonça 1744 (BM, COI), between Camacupa and Bié, alt. 1400-1700 m, 7 May 1937 (Note: this specimen was cited in Exell \& Mendonça (1951: 371) as M. elegans, but Duvigneaud in 1950 already identified it as "cf. spec. nova ad caloneurus"); Henriques 1373 (LISC), Kuito,10 km from Cachingues to Chitembo, 7 Apr. 1971; Monteiro \& Murta 1917 (COI, LISC), Cuemba, Cachingues, alt. c. 1300 m, 17 Sept. 1966; Raimundo, Matos \& Figueira 60 (LISC), Chissamba, alt. c. 1400 m, 11 Feb. 1970 .

\section{Monotes pearsonii H.H.Bancr.}

Monotes pearsonii H.H.Bancr. (1936a) 44. - Type: Pearson 2649 (holo K, seen in JSTOR; iso FHO), Angola, Huíla, 8 May 1909.

Shrub or tree up to $6 \mathrm{~m}$ tall. Leaves $6-9.5$ by $4-5.5 \mathrm{~cm}$, obovate or elliptic, truncate to slightly emarginate at the apex, often mucronate; rounded to truncate at the base; upper surface with short simple and stellate hairs and resiniferous glands; lower surface covered with a short and dense indumentum cream-whitish, not hiding the reticulation, $12-15$ pairs of lateral nerves; petiole $1.6-2.1 \mathrm{~cm}$ long, terete, with simple and stellate hairs. Inflorescences few-flowered, $4-8 \mathrm{~cm}$ long. Flowers with sepals $2-3 \mathrm{~mm}$ long, tomentose, petals $8-9 \mathrm{~mm}$ long, sericeotomentose, anthers with a widely triangular to subquadrate appendage at he apex. Fruits globose, depressed at the apex c. $1.8 \mathrm{~cm}$ diam; wings narrowly lanceolate, up to 8 by $2 \mathrm{~cm}$.

Ecology - In woodland; altitude 1450-1800 m.

Distribution - Endemic to southern Angola. - CC: Mendes 1999 (LISC). - HI: Dechamps, Murta \& Silva 1225 (LISC); Pearson 2649 (K).

Conservation status - Monotes pearsonii is known from three collections made in three different localities, but several other collecting events took place at least in one of these locations and no further specimens are known. With just $12 \mathrm{~km}^{2}$ of known area of occupancy and three localities, M. pearsonii is rare and it should be considered as vulnerable by having a very small and restricted population (VU D2).

\section{Monotes rubriglans H.H.Bancr.}

Monotes rubriglans H.H.Bancr. (1937) 138. - Type: Bonnefoux \& Villain 57 (holo P, seen in JSTOR; iso BM), Angola, Huila, s.d.

Tree up to $7 \mathrm{~m}$ tall. Leaves $10-15$ by $5-8 \mathrm{~cm}$, elliptical or obovate, emarginate at the apex, rounded to slightly cordiform at the base; upper surface glabrescent, except for the midrib, with simple hairs and glands; lower surface with the interreticular areoles glabrous and the nerves with sparse, simple hairs and numerous glandulous hairs, basal gland small, rounded, redcoloured; $12-14$ pairs of lateral nerves; petiole 1.1-2 cm long. Inflorescences not seen. Fruits globose c. $1 \mathrm{~cm}$ diam; wings narrowly elliptical, $3-4.5$ by $1-1.5 \mathrm{~cm}$.
Ecology — In xerophilous woodland, savanna woodland and river banks.

Distribution - Endemic to southern and central Angola. - HI: Bonnefoux \& Villain 57 (P). - LS: Exell \& Mendonça 288, 326 (COI, LISC). - MA: Barbosa 11352 (LISC).

Conservation status - This species is known from four collections and four different localities. Monotes rubriglans is rare and it should be considered as vulnerable by having a very small and restricted population (VU D2).

Vernacular name - muleletua (chokwe, Exell \& Mendonça 288)

\section{Monotes xasenguensis H.H.Bancr.}

Monotes xasenguensis H.H.Bancr. (1939b) 111. — Syntypes: Gossweiler 11755 (holo BM, n.v.; iso COI), Angola, Lunda, Xa-Sengue, Apr. 1937

Tree $15 \mathrm{~m}$ tall. Leaves $7-10$ by $2-3 \mathrm{~cm}$, elliptical to obovateelliptical; rounded, obtuse or acute at the apex, rounded, acute or slightly auriculate at the base; upper surface glabrous; lower surface glabrous, with the midrib and lateral nerves prominent, $13-18$ pairs of lateral nerves; petiole $0.7-1.4 \mathrm{~cm}$ long. Inflorescences not seen. Fruits subglobose, c. $0.9 \mathrm{~cm}$ diam; wings C. 3 by $0.7 \mathrm{~cm}$.

Ecology - In xerophilous forest.

Distribution - Endemic to north-east Angola. - LS: Gossweiler 11755 (COI).

Conservation status - Monotes xasenguensis is known from a single collection. As no other collection events are known for that locality, the species should be considered as Data Deficient with insufficient information (DD 3).

Note - This species is known only from the type collection. Nevertheless, the separation from the nearest species, M. glaber, seems to be effective and the species must be maintained.

\section{INSUFFICIENTLY KNOWN SPECIES NOT INCLUDED IN THIS TREATMENT}

Duvigneaud (1961: 412) referred to Monotes redheadii P.A. Duvign. for Angola without specimen citation. No collections were found to confirm this record.

Monotes glandulosus Pierre (1897)is only known from a single collection, without data on location, habitat and habit, but apparently collected in Angola, where the species is supposed to be endemic. As noted by Gilg (1908b) it is very similar to M. caloneurus. There are no known specimens collected in the last century. Remaining doubts on the species characterisation and about the country where the type specimen was collected, the species is not considered in this work.

\section{GEOGRAPHICAL DISTRIBUTION AND CONSERVATION STATUS OF THE ENDEMIC SPECIES}

The species of Monotes endemic to Angola are found mainly in dry to subxerophytic Brachystegia - Isoberlinia woodland and savanna woodland. Regarding the geographical distribution of these endemic species of Monotes in the Angolan provinces, all the collections are from the south-western, central and north-eastern provinces. No records are known from the south-eastern and north-western parts of the country, including Cabinda (Map 1, 2). As Monotes are found mainly in woodland and savanna woodland, and several species of the genus are present in the neighbouring territories (e.g. Duvigneaud 1949, 1961), this bias is probably due to an unbalanced collection effort in the Southeast (namely in the Cuando-Cubango province) of the Angolan territory; and to their effective absence in the 


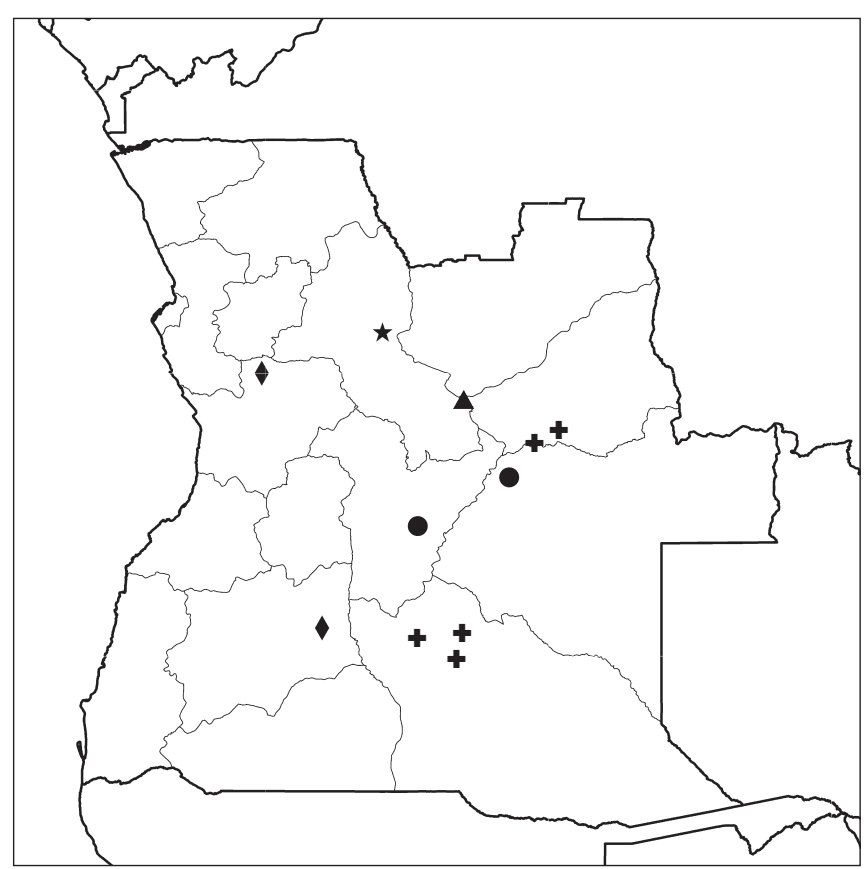

Map 1 Distribution of the following endemic species of Monotes in Angola: M. carrissoanus (๑), M. dawei $(\downarrow), M$. gossweileri (†), M. hutchinsonianus $(\star)$, M. hypoleucus $(\boldsymbol{\square})$, M. xasenguensis $(\boldsymbol{\Delta})$.

Northwest (Zaire and Uige provinces) and Cabinda, in which the forest is dominant.

There are no Monotes among the vascular plant species referred to as threatened in Angola in published works (Dombo et al. 2002, Costa et al. 2009), and only Marquesia macroura is considered in the Low Risk class. Nevertheless, those studies are largely incomplete and a huge amount of work is needed to assess the real status of plant and animal populations in the country. The application of the IUCN Red List criteria (IUCN 2010) to evaluate the conservation status of the species of Monotes endemic to Angola poses some difficulties due to the scarcity and age of collections for most species. For some of these species only one or a few collections are available, in most cases dating from several decades or even a century ago. Out of the ten species of Monotes endemic to Angola, two are only known from the type collection (M. hutchinsonianus and $M$. xasenguensis). Three species, $M$. carrissoanus, $M$. dawei and $M$. noldeae, are known from two collections each. On the other hand, using the 2 by $2 \mathrm{~km}$ grid suggested by IUCN (2010) as a base to determine the area of occupancy (AOO) of species, and the criterion of five or less known locations, all the species of Monotes endemic to Angola can be considered as vulnerable. Nevertheless, for some species the available data are insufficient to assign a conservation status and they must be considered as Data Deficient. Hence, with the available data, from the ten Monotes species endemic to Angola, eight can be considered as vulnerable because of their very small or restricted population (VU D2) and two are Data Deficient with insufficient information (DD 3).

\section{FINAL REMARKS}

Angola shows a remarkable diversity in the Dipterocarpaceae family and in particular in the genus Monotes, bearing more than half of the species described so far, from which ten are endemic to the country. However, the available herbarium material is aged and it is scarce for several species, in particular the endemics. On the other hand, the distinctive characters more commonly used for species differentiation are often difficult

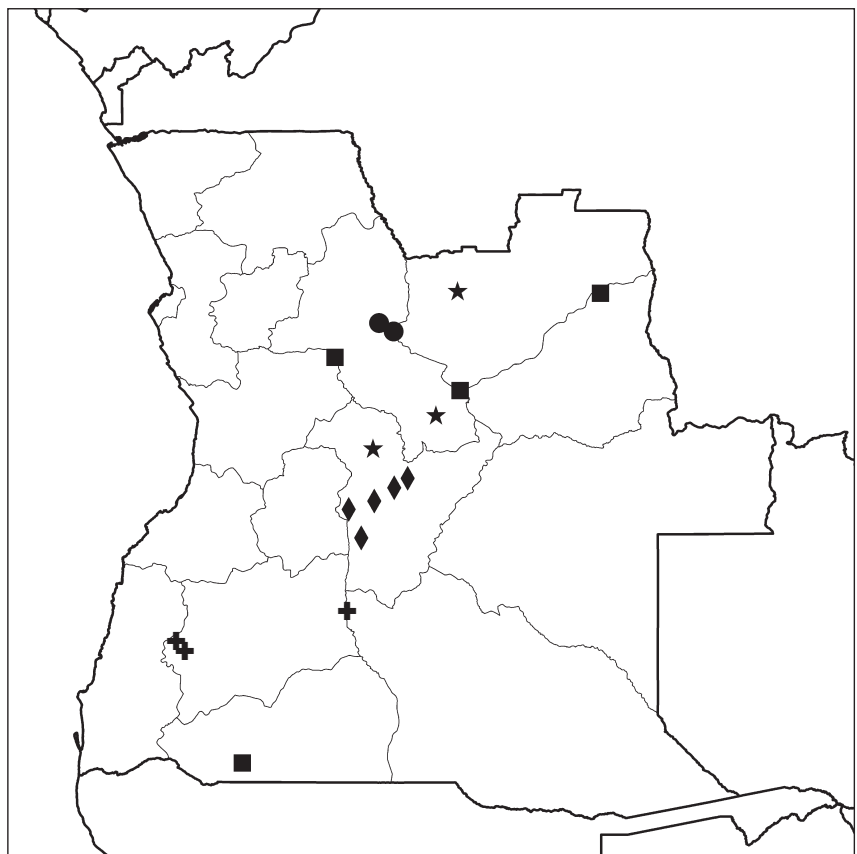

Map 2 Distribution of the following endemic species of Monotes in Angola:

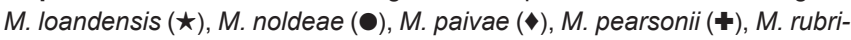
glans ( $\mathbf{\square})$.

to assess and with continuous variation. In this context, the taxonomy of the Dipterocarpaceae in Southern Africa and particularly in Angola remain to be clarified in some extent and further collections are needed in order to make possible a better characterisation of each taxon both in the taxonomical and ecological aspects.

Acknowledgements This work was developed in the scope of project IMBAMBA - reference PTDC/BIA-QOR/66702/2006, funded by the Portuguese Foundation for Science and Technology (FCT). The authors are indebted to Estrela Figueiredo for its revision of the manuscript and useful suggestions, to Alexandra Mariano for the diagnose translation into Latin, and to the anonymous reviewers for comments and suggestions.

\section{REFERENCES}

Ashton PS. 1982. Dipterocarpaceae. Flora Malesiana 9, 2: 237-552. Nijhoff Publishers, The Hague.

Aubréville A. 1976. Essai d'interprétation nouvelle de la distribution des Diptérocarpacées. Adansonia, sér. 2, 16: 205-210.

Bancroft HH. 1935. The taxonomic history and geographical distribution of the Monotoideae. American Journal of Botany 22, 5: 505-519.

Bancroft HH. 1936a. New Angolan species of Monotes. Boletim da Sociedade Broteriana, 2a sér. 11: 43-45.

Bancroft HH. 1936b. New species of Monotes from Angola. The Journal of Botany 74: 225-226.

Bancroft HH. 1937. Dipterocarpaceae. In: Exell AW, Mendonça FA (eds), Conspectus Florae Angolensis 1, 1: 132-143. Junta de Investigações Coloniais, Lisboa.

Bancroft HH. 1939a. African Dipterocarps: an historical and taxonomic survey of the genus Monotes A.DC. Boletim da Sociedade Broteriana, 2a sér. 13: 326-389.

Bancroft HH. 1939b. The Carrisso botanical mission to Angola: new species of Monotes. The Journal of Botany 77: 110-112.

Costa E, Dombo A, Paula M. 2009. Plantas ameaçadas em Angola. Centro de Botânica - UAN, Luanda.

Craven P. 1999. A preliminary checklist of Namibian plant species. Southern African Botanical Diversity Report No. 7. Pretoria, SABONET.

Dayanandan S, Ashton PS, Williams SM, Primack RB. 1999. Phylogeny of the tropical tree family Dipterocarpaceae based on nucleotide sequences of the chloroplast RBCL gene. American Journal of Botany 86: 1182-1190. De Candolle A. 1868. Dipterocarpae. In: De Candolle A (ed), Prodromus systematis naturalis Regni vegetabilis 16, 2: 604-637. Masson \& Fils, Paris. 
De Wildeman E. 1915. Decades novarum specierum Florae Congolensis III. Bulletin du Jardin Botanique de l'État 5: 1-108.

De Wildeman E. 1927. Plantae Bequaertianae 4. Buyens, Gand; Lechevalier, Paris.

Dombo A, Da Costa E, Neto G. 2002. Angola. In: Golding JS (ed), Southern African plant red data lists. Southern African Botanical Diversity Network Report 14: 8-11. Pretoria, SABONET.

Duvigneaud P. 1949. Le genre Monotes (Diptérocarpacées) dans les forêts claires du Congo Méridional et des regions voisines. Lejeunia 13: 39-65.

Duvigneaud P. 1959. New and little known species from the Flora Zambesiaca area. Boletim da Sociedade Broteriana, 2a sér. 33: 101-102.

Duvigneaud P. 1961. Dipterocarpaceae. In: Exell AW, Wild H (eds), Flora Zambesiaca 1, 2: 407-420. Crown Agents for Overseas Governments and Administration, London.

ESRI. 2010. ArcGIS 10.0. Environmental Systems Research Institute, Inc., Redlands, California.

Exell AW. 1932. John Gossweiler's plants from Angola and Portuguese Congo. The Journal of Botany (Supplement Polypelalaceae) 70: 219-220.

Exell AW, Mendonça FA. 1951. Dipterocarpaceae adenda e corrigenda. Conspectus Florae Angolensis 1, 2: 370-372. Junta de Investigações Coloniais, Lisboa.

Figueiredo E, Smith G. 2008. Plants of Angola / Plantas de Angola. Strelitzia 22. South African National Biodiversity Institute, Pretoria.

Fries RE. 1914a. Die Gattung Marquesia und ihre systematische Stellung. Botanische Jahrbücher für Systematik, Pflanzengeschichte und Pflanzengeographie 51: 349-355.

Fries RE. 1914b. Dipterocarpaceae. Wissenschaftliche Ergebnisse der Schwedischen Rhodesia-Kongo-Expedition, 1911-1912, unter Leitung von Eric Graf von Rosen. Band 1: 153-155. Aftonbladtts Druckerei, Stockholm.

Gilg E. 1899. Uber die systematische Stellung der Gattung Monotes und deren Arten. Botanische Jahrbücher für Systematik, Pflanzengeschichte und Pflanzengeographie 28: 127-137.

Gilg E. 1903. Dipterocarpaceae. In: Warburg O (ed), Kunene-SambesiExpedition H. Baum: 307-308. Verlag des Kolonial-Wirtschaftlichen Komitees, Berlin.

Gilg E. 1908a. Flacourtiaceae Africanae. Botanische Jahrbücher für Systematik, Pflanzengeschichte und Pflanzengeographie 40: 444-518.

Gilg E. 1908b. Weitere beiträge zur kenntniss der africanischen Dipterocarpacen-Gattung Monotes. Botanische Jahrbücher für Systematik, Pflanzengeschichte und Pflanzengeographie 41: 287-292.

Hiern WP. 1896. Catalogue of the African plants collected by Dr. Friedrich Welwitsch in 1853-61. Vol. I. British Museum (Natural History), London. Holmgren PK, Holmgren NH, Barnett LC. 1990. Index Herbariorum. Ed. 8. Regnum Vegetabile 120.
Hutchinson J. 1931. General Smuts' botanical expedition to Northern Rhodesia, 1930. Bulletin of Miscellaneous Information, Kew 1931: 225-254.

IUCN Standards and Petitions Subcommittee. 2010. Guidelines for using the IUCN red list categories and criteria. Version 8.1. Downloadable from http://intranet.iucn.org/webfiles/doc/SSC/RedList/RedListGuidelines.pdf. Kostermans AJGH. 1985. Family status for the Monotoideae Gilg and the Pakaraimoideae Ashton, Maguire and de Zeeuw (Dipterocarpaceae). Taxon 34, 3: 426-435.

Kostermans AJGH. 1989. Monotaceae, a new family allied to Tiliaceae. Taxon 38, 1: 123-124.

Londoño AC, Alvarez E, Forero E, Morton CM. 1995. A new genus and species of Dipterocarpaceae from the Neotropics I. Introduction, taxonomy, ecology and distribution. Brittonia 47: 225-236.

Maguire B, Ashton PS. 1977. Pakaraimoideae, Dipterocarpaceae of the Western hemisphere. II. Systematic, geographic and phyletic considerations. Taxon 26, 4: 343-368.

Maury-Lechon G, Curtet L. 1998. Biogeography and evolutionary systematics of Dipterocarpaceae. In: Appanah S, Turnbull JM (eds), A review of Dipterocarps: Taxonomy, ecology and silviculture: 5-44. CIFOR, Bogor.

Mildbraed GWJ. 1939. Eine neue Marquesia aus Angola. Notizblatt des Botanischen Gartens und Museums zu Berlin-Dahlem. Berlin-Dahlem 14: $379-380$.

Ministério do Ultramar. 1963-1967. Carta de Angola 1 : 100 000. Luanda. Oliver D. 1868. Flora of Tropical Africa, Vol. 1. Reeve \& Co. Ltd., Ashford.

Phiri PSM. 2005. A checklist of Zambian vascular plants. Southern African Botanical Diversity Network Report No 32. Pretoria, SABONET.

Pierre JBL. 1897. Sur le Monotes glandulosa sp. nov. Bulletin Mensuel de la Société Linnéenne de Paris 2: 1298-1299.

Sosef MSM. 2010a. Trillesanthus, a validly published name to replace the African genus Marquesia (Dipterocarpaceae). Blumea 55: 88-90.

Sosef MSM. 2010b. Dipterocarpaceae. In: Sosef MSM, Florence J, Banak LN, Bourobou HPB (eds), Flore du Gabon 41: 35-38. Netherlands Centre for Biodiversity Naturalis, Wageningen.

Sprague TA. 1909. Diagnoses Africanae: XXX. Bulletin of Miscellaneous Information, Kew 1909: 305-309.

Van Rijckevorsel P. 2011. (6-8) Proposals to add two Tabulae herbarii L. Pierre or the entire set to the "Opera utique oppressa". Taxon 60, 1: 287-298.

Verdcourt B. 1989. Dipterocarpaceae. In: Polhill RM (ed), Flora of Tropical East Africa. Balkema, Rotterdam.

Welwitsch F. 1869. Sertum Angolense, sive stirpium quarundam novarum vel minus cognitarum in itinire per Angolam et Benguellam observatorum descriptio icinibus illustrata. Transactions of the Linnean Society of London 27, 1: 1-94

Willis F, Moat J, Paton A. 2003. Defining a role for herbarium data in Red List assessments: a case study of Plectranthus from eastern and southern Tropical Africa. Biodiversity and Conservation 12: 1537-1552.

\section{INDEX TO SCIENTIFIC NAMES}

Accepted taxa are in roman, synonyms in italics and the new name in bold. insuf = insufficiently known. Numbers refer to the species number as used in this work.

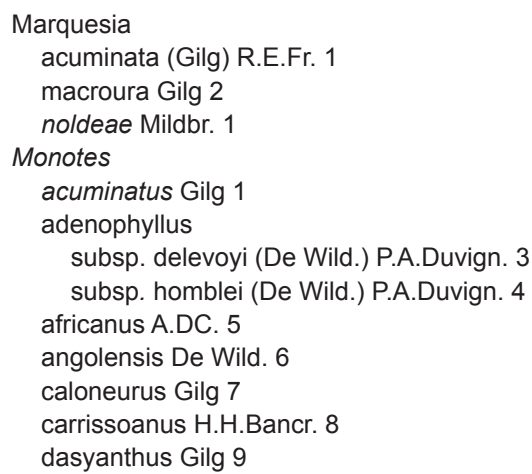

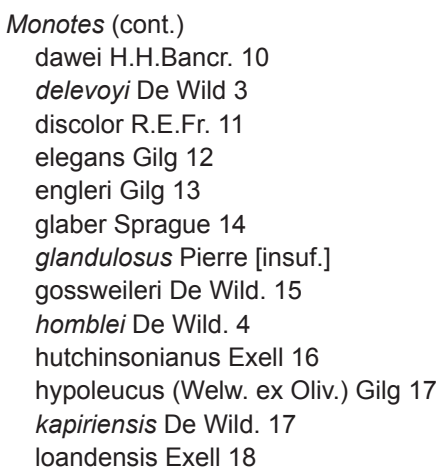

\author{
Monotes (cont.) \\ magnificus var. homblei (De Wild.) P.A.Duvign. 4 \\ mutetetwa P.A.Duvign. 19 \\ noldeae H.H.Bancr. 20 \\ oblongifolius Hutch. 6 \\ paivae L.Catarino \& E.S.Martins 21 \\ pearsonii H.H.Bancr. 22 \\ redheadii P.A.Duvign. [insuf.] \\ rubriglans $\mathrm{H}$.H.Bancr. 23 \\ sapinii De Wild. 2 \\ tomentellus Hutch. \& Milne-Redh. 13 \\ xasenguensis H.H.Bancr. 24 \\ Vatica africana (A.DC.) Welw. 5 \\ var. hypoleuca Welw. ex Oliv. 17
}

